\section{PRESENCE OF INDIAN PALM SQUIRREL FUNAMBULUS PALMARUM LINNAEUS IN SOUTHERN ARAVALLIS}

\section{Satish Kumar Sharma}

Range Forest Officer, Phulwari Wildlife Sanctuary, Kotra, Udaipur District, Rajasthan 307025, India

web supplement

Five species of striped squirrels, viz., F. layardi, F. palmarum, $F$. pennantii, $F$. sublineatus and $F$. tristriatus are confined to South Asia. Four of these species are restricted to southern India and/or Sri Lanka. Only F. pennantii occurs in northern India and extends into Pakistan and Nepal (Ellerman, 1961; Ellerman \& Morrison-Scott, 1951; Gurung \& Singh, 1996; Srinivasulu et al., 2004).

During 1986, while on an academic tour, I heard a few bird-like repeated calls in the forest of Jhadol range in Udaipur district in Rajasthan. The calls were quite similar to that of the Indian Palm Squirrel F. palmarum. Unfortunately, I could not see the animal owing to high density of vegetation cover. In 1992, I again started my mission to confirm the presence of Indian Palm Squirrel in southern Aravallis in Rajasthan and Gujarat. With the help of local tribals I succeeded in searching the Indian Palm Squirrel in various forest pockets of Vijai Nagar, Kotra, Jhadol, Ogna, Sayra, Mamer, Panarwa and Bokhada forest ranges as given in Table 1 and Figure 1.

F. palmarum is endemic to South Asia. So far, its distribution is known from Andhra Pradesh, Chattisgarh, Jharkhand, Karnataka, Kerala, Maharashtra, Madhya Pradesh, Orrisa, Tamil Nadu and West Bengal in India besides Sri Lanka. The present observation confirms the presence of this species in Gujarat and southern Rajasthan where it is present in the dense forest pockets of the Aravallis (Image $1^{\mathrm{w}}$ ).

Funambulus palmarum is a perfect forest species in southern Aravallis. It is totally absent from open forests, agriculture fields and human habitations. It prefers dense valleys and foothills of interior forest zone. Nests of Indian Palm Squirrel are seen on extremities of Dendrocalamus strictus clumps in the foothills of hilly forest areas. The sacred groves of Jargaji and Kamalnath temples in southern Aravallis are the best localities to watch this species at close quarters. Both the sacred groves are situated amidst dense forest. Occassional road kills of this species are seen on Ogna-Gogunda road which passes through Nal-Mokhi forest zone (Image $1^{\mathrm{w}}$ ).

The India Palm Squirrel Funambulus palmarum is considered a southern Indian species. Six races of $F$. palmarum are in distribution in Sri Lanka and peninsular India (Ellerman \& Morrison-Scott, 1951; Ellerman 1961) as given in Table 2. No race of $F$. palmarum has been reported from north of Madhya Pradesh.

The race, confined to southern Aravallis is probably $F$. palmarum robertsoni, which is distributed up to Pachmari, Hoshangabad, Asirgarh, Sival, Nimar, Dhain, Rorighat, Kolkaz, Berar in central India (Ellerman, 1961). The forest habitats near Melghat, Budni, Hoshangabad, Itarsi, Kiratgarh, Dhara Khoh, Maramjhiri, Barsali etc., in central India are quite similar to that of the forests of southern Aravallis. Due to similarity in habitat many peninsular and Deccan floral and faunal species are confined to southern Aravallis; the Southern Indian Giant Flying Squirrel Petaurista philippensis philippensis (Elliot, 1839) is one of them. F. palmarum and $P$. philippensis are present sympatrically in southern Aravallis.

Extensive surveys are required to know the exact distribution limits of the Indian Palm Squirrel in Rajasthan and Gujarat and whether the population under study is an isolated one or contiguous with those in Madhya Pradesh.

\section{REFERENCES}

Ellerman, J.R. (1961). The Fauna of India including Pakistan, Burma and Ceylon: Mammalia, Rodentia. Volume 3 (in 2 parts). $2^{\text {nd }}$ edition. Zoological Survey of India, Calcutta, Vol. 1: 1-482pp. \& Vol. 2: 483 $884 \mathrm{pp}$

Ellerman, J.R. and T.C.S. Morrison-Scott (1951). Checklist of

${ }^{w}$ see Image 1 in the web supplement at www.zoosprint.org

Table 1. Presence of Indian Palm Squirrel in southern Aravallis.

\begin{tabular}{|c|c|c|c|c|c|c|c|}
\hline & Name of locality & Name of range* & $\begin{array}{l}\text { Tehsil } \\
\text { (Taluka) }\end{array}$ & District & State & $\begin{array}{l}\text { Density of } \\
\text { forest }\end{array}$ & $\begin{array}{l}\text { Local status } \\
\text { of animal }\end{array}$ \\
\hline \multirow[t]{9}{*}{1.} & Phulwari Wildlife Sanctuary & & & & & & \\
\hline & (a) Katawali Jer (Daiya Forest Block) & Panarwa (WL) & Jhadol & Udaipur & Rajasthan & Dense & C \\
\hline & (b) Bhildi mata (Phulwari Forest Block) & Panarwa (WL) & Jhadol & Udaipur & Rajasthan & Dense & C \\
\hline & (c) Kanchan (Phulwari Forest Block) & Kotra (WL) & Kotra & Udaipur & Rajasthan & Dense & $\mathrm{C}$ \\
\hline & (d) Luhari Ghati (Phulwari Forest Block) & Kotra (WL) & Kotra & Udaipur & Rajasthan & Dense & $\mathrm{C}$ \\
\hline & (e) Bhader Baosi (Devil Forest Block) & Kotra (WL) & Kotra & Udaipur & Rajasthan & Dense & C \\
\hline & (f) Kaduwa Mahuda (Dhedmariya Forest Block) & Kotra (WL) & Kotra & Udaipur & Rajasthan & Dense & C \\
\hline & $\begin{array}{l}\text { (g) Dhovaniya Kund and Ghodapadiya } \\
\text { (Dhedmariya Forest Block) }\end{array}$ & Kotra (WL) & Kotra & Udaipur & Rajasthan & Dense & C \\
\hline & (h) Village Amba (Ada Haldu Forest Block) & Mamer (WL) & Kotra & Udaipur & Rajasthan & Dense & LC \\
\hline 2. & Ram Kunda temple (Ram Kunda Forest Block) & Orna $(\mathrm{T})$ & Jhadol & Udaipur & Rajasthan & Dense & LC \\
\hline 3. & Nal-Mokhi village (Nal-Mokhi Forset Block) & Gogunda $(T)$ & Gogunda & Udaipur & Rajasthan & Dense & LC \\
\hline 4. & Jargaji temple sacred grove & Sayraa $(T)$ & Gogunda & Udaipur & Rajasthan & Dense & $\mathrm{C}$ \\
\hline 5. & Southern end of Kubhalgarh Wildlife Sanctuary & Bokhaada (WL) & Gogunda & Udaipur & Rajasthan & Dense & LC \\
\hline 6. & Kamalnath temple sacred grove & Jhadol & Jhadol & Udaipur & Rajasthan & Dense & A \\
\hline 7. & Polo forest & Vijai Nagar & Vijai Nagar & Sabar Kantha & Gujarat & Dense & $\mathrm{C}$ \\
\hline
\end{tabular}

${ }^{*}$ A - Abundant; C - Common; LC - Less Common; WL - Wildlife Range; T - Territorial Range 
Palaeartic and Indian Mammals 1758 to 1946. Trustees of British Museum (Natural History) London, 810pp.

Gurung, K.K. and R. Singh (1996). Mammals of Indian Subcontinent. Srinivasulu, C., S. Chakraborti and M.S. Pradhan (2004). Checklist of Sciurids (Mammalia: Rodentia: Sciuridae) of South Asia Zoos' Print Journal 19(2): 1351-1360.

\section{ACKnowledgements}

Author is very grateful to Shri Bharat Taimni, Shri Rahul Bhatnagar., Dr. S.S. Katewa, Dr. Chhaya Bhatnagar, Shri H.S. Solanki, Shri Fateh Singh Rathore, Shri Hom Kishor Mahawar, Shri Amrit Lal Meghwal, Shri Sundar Lal and members of Eco Development Committee, Phuldhariya for their cooperation and help during field studies.
Table 2. Distribution of races of Fumambulus palmarum in the Indian subcontinent

\begin{tabular}{lll}
\hline S.no. & Name of race & Distribution \\
\hline 1. & F. palmarum brodiei Blyth, 1849 & Sri Lanka \\
2. & F. palmarum kelaarti Layard, 1851 & Sri Lanka \\
3. & F. palmarum matugamensis Lindsay, 1926 & Sri Lanka \\
4. & F.palmarum palmarum (Linnaeus 1766) & Bihar, southern India \\
5. & F. palmarum bellaricus Wroughton, 1916 & southern Peninsular India \\
6. & F. palmarum robertsoni Wroughton, 1916 & Central India \\
\hline
\end{tabular}

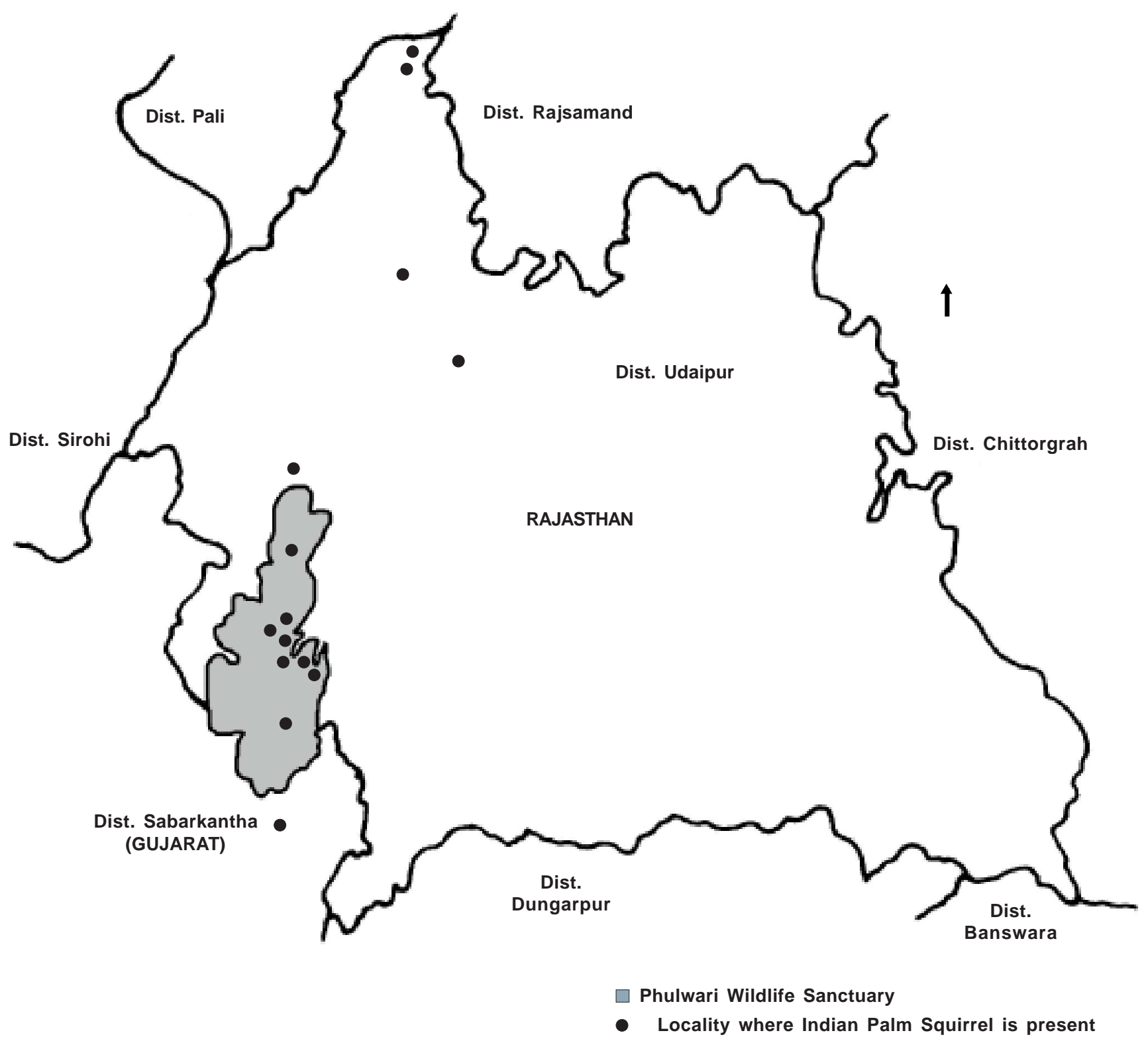

Figure 1. Distribution of Indian Palm Squirrel Funambulus palmarum in southern Aravallis 